\title{
Ocular Paraneoplastic Syndromes
}

\author{
Joanna Przeździecka-Dołyk ${ }^{1,2}{ }^{2}$ Anna Brzecka ${ }^{3}{ }^{(0)}$, Maria Ejma ${ }^{4}$, Marta Misiuk-Hojło ${ }^{1}$, \\ Luis Fernando Torres Solis ${ }^{5}$, Arturo Solís Herrera ${ }^{6}$, Siva G. Somasundaram ${ }^{7}$, \\ Cecil E. Kirkland ${ }^{7}$ (D) and Gjumrakch Aliev ${ }^{8,9,10,11, *(D)}$ \\ 1 Department of Ophthalmology, Wroclaw Medical University, Borowska 213, 50-556 Wrocław, Poland; \\ joanna.przezdziecka.dolyk@gmail.com (J.P.-D.); misiuk55@wp.pl (M.M.-H.) \\ 2 Department of Optics and Photonics, Wrocław University of Science and Technology, Wyspiańskiego 27, \\ 50-370 Wrocław, Poland \\ 3 Department of Pulmonology and Lung Oncology, Wrocław Medical University, Grabiszyńska 105, \\ 53-439 Wrocław, Poland; anna.brzecka@umed.wroc.pl \\ 4 Department of Neurology, Wroclaw Medical University, Borowska 213, 50-556 Wrocław, Poland; \\ mejma@interia.pl \\ 5 The School of Medicine, Universidad Autónoma de Aguascalientes, Aguascalientes 20392, Mexico; \\ lfts99@yahoo.com.mx \\ 6 Human Photosynthesis@ Research Centre, Aguascalientes 20000, Mexico; comagua2000@gmail.com \\ 7 Department of Biological Sciences, Salem University, Salem, WV 26426, USA; \\ siva.somasundaram@salemu.edu (S.G.S.); EKirkland@salemu.edu (C.E.K.) \\ 8 Sechenov First Moscow State Medical University (Sechenov University), St. Trubetskaya, 8, bld. 2, \\ 119991 Moscow, Russia \\ 9 Research Institute of Human Morphology, Russian Academy of Medical Science, Street Tsyurupa 3, \\ 117418 Moscow, Russia \\ 10 Institute of Physiologically Active Compounds, Russian Academy of Sciences, Chernogolovka, \\ 142432 Moscow, Russia \\ 11 GALLY International Research Institute, 7733 Louis Pasteur Drive, \#330, San Antonio, TX 78229, USA \\ * Correspondence: aliev03@gmail.com or cobalt55@gallyinternational.com; \\ Tel.: +1-210-442-8625 or +1-440-263-7461
}

Received: 6 September 2020; Accepted: 8 November 2020; Published: 10 November 2020

\begin{abstract}
Ocular-involving paraneoplastic syndromes present a wide variety of clinical symptoms. Understanding the background pathophysiological and immunopathological factors can help make a more refined differential diagnosis consistent with the signs and symptoms presented by patients. There are two main pathophysiology arms: (1) autoimmune pathomechanism, which is presented with cancer-associated retinopathy (CAR), melanoma-associated retinopathy (MAR), cancer-associated cone dysfunction (CACD), paraneoplastic vitelliform maculopathy (PVM), and paraneoplastic optic neuritis (PON), and (2) ectopic peptides, which is often caused by tumor-expressed growth factors (T-exGF) and presented with bilateral diffuse uveal melanocytic proliferation (BDUMP). Meticulous systematic analysis of patient symptoms is a critical diagnostic step, complemented by multimodal imaging, which includes fundus photography, optical coherent tomography, fundus autofluorescence, fundus fluorescein angiography, electrophysiological examination, and sometimes fundus indocyjanin green angiography if prescribed by the clinician. Assessment of the presence of circulating antibodies is required for diagnosis. Antiretinal autoantibodies are highly associated with visual paraneoplastic syndromes and may guide diagnosis by classifying clinical manifestations in addition to monitoring treatment.
\end{abstract}

Keywords: cancer-associated retinopathy; melanoma-associated retinopathy; cancer-associated cone dysfunction; paraneoplastic syndromes; vitelliform maculopathy; optic neuritis; uveal melanocytic proliferation; extracellular vesicles 


\section{Introduction}

Sawyer et al. reported the first report of systemic cancer causing visual deterioration and retinal changes in 1976. This opened a new era of research into ocular paraneoplastic syndromes (OPNS). Surprisingly, strict diagnostic criteria remain to be developed. The reason is perhaps the various presentations of OPNS, such as paraneoplastic retinopathy, paraneoplastic optic neuropathy, and paraneoplastic tonic pupils. However, the majority of Paraneoplastic Syndrome (PNS) occur when immune-mediated cross-reactivity involving tumor antigens causes collateral damage to normal host tissues. Alternatively, there are PNS that appear to be caused by the ectopic production of hormones or growth factors that act at a great distance from their production site (Figure 1) [1]. Understanding this main division contributes to a better understanding of OPNS pathophysiology.

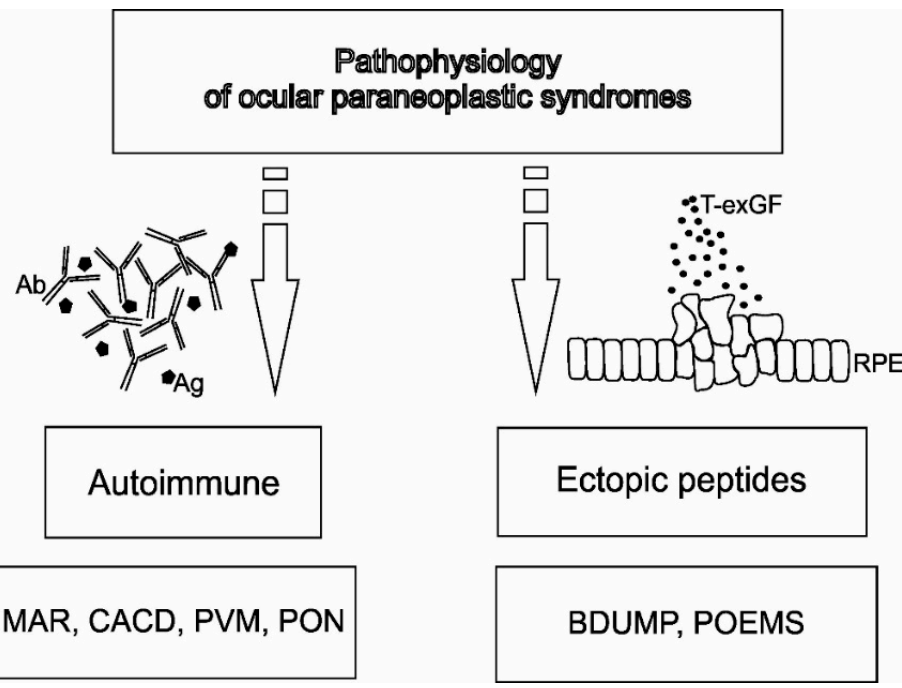

Figure 1. The pathophysiology of ocular paraneoplastic syndromes (OPNS). Autoimmune pathomechanism is presented with cancer-associated retinopathy (CAR), melanoma-associated retinopathy (MAR), cancer-associated cone dysfunction (CACD), paraneoplastic vitelliform maculopathy PVM), and paraneoplastic optic neuritis (PON). Ectopic peptides, caused by tumor-expressed growth factors (T-exGF), are presented with bilateral diffuse uveal melanocytic proliferation (BDUMP) and polyneuropathy, organomegaly, endocrinopathy, monoclonal gammopathy, and skin changes syndrome (POEMS).

The overall incidence of PNS is estimated at about $10 \%$ of neoplastic patients. Darnell et al., similar to De Salvo et al., estimated the incidence of OPNS and neurologic paraneoplastic syndromes to be even lower at $0.01 \%$ of cancer patients [2,3].

The aim of this paper is to summarize the clinical symptoms and signs associated with different OPNS. Our database search strategy is discussed in the attached file (Supplementary Materials). After removing duplicated studies, we selected 312 published reports for our analysis. We narrowed our review to publications in the past six years that address clinical evaluation and diagnosis.

\section{Clinical Evaluation}

Tables 1 and 2 provide a summary of clinical presentations that cover the main types of paraneoplastic retinopathies and neuropathies.

Clinicians must take into account the fact that misdiagnosis potential is increased with other ophthalmological changes, such as age-related macular degeneration, pigment epithelium detachment, vitelliform maculopathy, retinitis pigmentosa, stationary night blindness, intraocular inflammation, glaucomatous optic nerve atrophy, or typical optic neuritis.

Table 3 summarizes underlying neoplasm, circulating antibodies or growth factors, and target cells within the visual system. 
Table 1. Summary of clinical features in different types of paraneoplastic retinopathies based on the included articles.

\begin{tabular}{|c|c|c|c|c|c|}
\hline Clinical Features & CAR & CACD & PVM & MAR & BDUMP \\
\hline Onset & $\begin{array}{l}\text { Acute, sudden (few days } \\
\text { to several months) }\end{array}$ & Subacute & $\begin{array}{l}\text { Acute or subacute (few } \\
\text { weeks to several years) }\end{array}$ & $\begin{array}{l}\text { Acute (few weeks to } \\
\text { months), may be sudden }\end{array}$ & $\begin{array}{c}\text { Acute, sudden } \\
\text { (several months) }\end{array}$ \\
\hline Ocular symmetry & $\begin{array}{l}\text { Bilateral with asymmetric } \\
\text { presentation }\end{array}$ & $\begin{array}{c}\text { Often } \\
\text { symmetric }\end{array}$ & $\begin{array}{l}\text { Bilateral with asymmetric } \\
\text { presentation }\end{array}$ & Bilateral & $\begin{array}{c}\text { Bilateral with } \\
\text { asymmetric presentation }\end{array}$ \\
\hline Photosensitivity & +++ & +++ & - & - & - \\
\hline Photopsias & +++ & + & - & +++ & - \\
\hline Glare & +++ prolonged & - & ++ & - & - \\
\hline Halo & - & - & +++ & - & - \\
\hline Starburst & - & - & - & - & - \\
\hline Color discrimination problems (basic colors & ++ & +++ & - & - & - \\
\hline Disturbed color vision (color desaturation) & ++ & +++ & - & ++ & - \\
\hline Night blindness & +++ & - & - & +++ & - \\
\hline Prolonged adaptation to darkness & +++ & - & - & + & - \\
\hline $\begin{array}{l}\text { Improvement of visual acuity while } \\
\text { wearing sunglasses }\end{array}$ & - & +++ & - & - & - \\
\hline $\begin{array}{l}\text { Significant decrease of visual acuity during } \\
\text { the day }\end{array}$ & - & + & +++ & - & - \\
\hline Phosphenes (visual hallucinations) & +++ & - & +++ & ++ & - \\
\hline Sudden shimmering & - & - & + & +++ & - \\
\hline Sudden flickering & ++ & - & - & +++ & - \\
\hline $\begin{array}{l}\text { Increased contrast sensitivity } \\
\text { (hyperphotosensitivity) }\end{array}$ & - & - & - & +++ & - \\
\hline $\begin{array}{l}\text { Increased color contrast sensitivity } \\
\text { (hyperphotosensitivity) }\end{array}$ & - & - & - & + & - \\
\hline Pain of the eye & - & - & - & - & $+/-$ \\
\hline Feeling of "full" eyes & - & - & - & - & $+/-$ \\
\hline
\end{tabular}

CAR—cancer-associated retinopathy; CACD—cancer-associated cone dysfunction; PVM—paraneoplastic vitelliform maculopathy; MAR—melanoma-associated retinopathy; BDUMP—bilateral diffuse uveal melanocytic proliferation; "-" - absent, "+/"- possibly present, "+"—present, "++"—strongly associated, "+++"—characteristic to this entry. 
Table 2. Summary of clinical work-up results in different paraneoplastic retinopathies based on the included articles.

\begin{tabular}{|c|c|c|c|c|c|}
\hline Clinical Work-Up & CAR & CACD & PVM & MAR & BDUMP \\
\hline BCVA & Severely decreased & $\begin{array}{l}\text { Mildly to moderately } \\
\text { decreased }\end{array}$ & $\begin{array}{c}\text { Blurred vision, mildly } \\
\text { decreased }\end{array}$ & $\begin{array}{l}\text { Mildly to severely } \\
\text { decreased }\end{array}$ & Moderately to severely decreased \\
\hline Visual field & $\begin{array}{l}\text { Central or ring scotoma, } \\
\text { peripheral scotomas }\end{array}$ & Central scotoma & $\begin{array}{l}\text { Central/paracentral } \\
\text { scotoma }\end{array}$ & Central/paracentral scotoma & Nonspecific \\
\hline OCT signs & $\begin{array}{l}\text { Loss of outer retinal } \\
\text { structures, including } \\
\text { ellipsoid and } \\
\text { interdigitation zone } \\
\text { (central and peripheral) }\end{array}$ & $\begin{array}{l}\text { Central loss of outer } \\
\text { retinal structures, } \\
\text { including ellipsoid and } \\
\text { interdigitation zone with } \\
\text { normal periphery }\end{array}$ & $\begin{array}{l}\text { Vitelliform submacular } \\
\text { deposits on the pigment } \\
\text { epithelium that elevate } \\
\text { the neurosensory retina }\end{array}$ & $\begin{array}{l}\text { Macular atrophy with } \\
\text { thinning of the inner retina }\end{array}$ & $\begin{array}{l}\text { Diffuse thickening of the uveal } \\
\text { tract with multiple elevated } \\
\text { pigment and nonpigment uveal } \\
\text { melanocytic tumors, possible } \\
\text { atrophy of choroidal vasculature } \\
\text { in Enhanced Depth Imaging (EDI) } \\
\text { scans was observed }\end{array}$ \\
\hline FAF & $\begin{array}{l}\text { Ring macular } \\
\text { hyperautofluorescence } \\
\text { with surrounding } \\
\text { hypoautofluorescence }\end{array}$ & Nonspecific & Nonspecific & Nonspecific & $\begin{array}{l}\text { Hypo-/hyperautofluorescence } \\
\text { characteristic "giraffe-like" } \\
\text { pattern lesions }\end{array}$ \\
\hline FFA & Normal/periphlebitis & Nonspecific & $\begin{array}{l}\text { Blocking effect on the } \\
\text { choroid with late-phase } \\
\text { contrast uptake }\end{array}$ & $\begin{array}{l}\text { Normal/vasculitis with } \\
\text { vascular diffusion }\end{array}$ & $\begin{array}{l}\text { Peripheral arterial nonperfusion } \\
\text { area, nummular or dermal loss of } \\
\text { retinal pigment epithelium, } \\
\text { exudative retinal detachment in } \\
\text { the late phases }\end{array}$ \\
\hline ICGA & Normal & Normal & Normal & Normal & $\begin{array}{l}\text { Normal/atrophy of choroidal } \\
\text { vasculature }\end{array}$ \\
\hline Full-field ERG & $\begin{array}{c}\text { Rods and cones equally } \\
\text { affected, firstly affecting } \\
\text { the a-wave, progression to } \\
\text { the "flat ERG" }\end{array}$ & $\begin{array}{l}\text { Affected only cone } \\
\text { response }\end{array}$ & $\begin{array}{l}\text { Nonspecific, variable } \\
\text { results }\end{array}$ & $\begin{array}{c}\text { Scotopic-disappearance or } \\
\text { microvoltage of b-wave, } \\
\text { normal a-wave. } \\
\text { Dysfunction of bipolar cells }\end{array}$ & $\begin{array}{l}\text { Reduction of scotopic and } \\
\text { photopic a- and b-wave } \\
\text { amplitude }\end{array}$ \\
\hline mfERG & Severely abnormal & Partially abnormal & Nonspecific & Mildly abnormal & Mildly abnormal \\
\hline EOG & Normal Arden ratio & Normal Arden ratio & Variable Arden ratio & Reduced Arden ratio & Normal Arden ratio \\
\hline
\end{tabular}


Table 3. Summary of underlying neoplasm, circulating antibodies or growth factors, and target cells within the visual system.

\begin{tabular}{|c|c|c|c|}
\hline OPNS & Neoplasm & Mediator * & Target Cell \\
\hline CAR & $\begin{array}{l}\text { Small-cell lung carcinoma, other lung neoplasm, } \\
\text { breast cancer, cancers of the cervix, ovary, uterus } \\
\text { and thymus, osteosarcoma, Warthin tumor of } \\
\text { parotid gland, prostate, pancreatic } \\
\text { neuroendocrine, small bowel, bladder and } \\
\text { laryngeal neoplasms, lymphomas (systemic } \\
\text { follicular cell lymphoma), and colon adenomas }\end{array}$ & $\begin{array}{l}\text { Recoverin, retinal enolase, TULP1, hsc-70 } \\
\text { and } 60 \text {, AIPL1, IRBP, PNR, GAPDH, } \\
\text { aldolase C, transducin- } \alpha \text {, GCAPs, HSP27 } \\
\text { and Rab6A, CA II, CRMP5, antiretinal } \\
\text { autoantibodies against arrestin and } \\
\text { 64-kDa and 94-kDa, C3, and C9 }\end{array}$ & $\begin{array}{l}\text { Rod, cone, bipolar cell, retinal } \\
\text { pigment epithelium }\end{array}$ \\
\hline CACD & $\begin{array}{l}\text { small-cell endometrial cancer, primary cervical } \\
\text { intraepithelial neoplasia, occult small cell lung } \\
\text { carcinoma, and laryngeal carcinoma }\end{array}$ & $\begin{array}{l}\text { Recoverin, retinal enolase, and protein } \\
\text { whose molecular weight is } 50 \text { and } 40 \mathrm{kDa}\end{array}$ & $\mathrm{L}$ and $\mathrm{M}$ than $\mathrm{S}$ cones \\
\hline PVM & cutaneous and mucosal melanoma, lymphoma & $\begin{array}{l}\text { PRDX3, ROS, bestropin-1, CA II, IRBP, } \\
\text { proteins } 35-\mathrm{kDa} \text { and } 68-\mathrm{kDa}\end{array}$ & Probably cones, bipolar cells, and rods \\
\hline MAR & cutaneous and mucosal melanoma & $\begin{array}{l}\text { TRPM1, MLSN1 } \alpha \text {-enolase, recoverin or } \\
\text { hsc-70, CA II, IRBP, bestrophin, myelin } \\
\text { basic protein, mitofilin, titin, and rod } \\
\text { outer segment proteins }\end{array}$ & Bipolar cells (preferably ON-bipolar cell) \\
\hline BDUMP & $\begin{array}{l}\text { ovarian, cervix, uterus, colon and rectum cancer, } \\
\text { gallbladder cancer, neoplasm of the } \\
\text { retroperitoneal space, and a variety of } \\
\text { lung cancers }\end{array}$ & $\begin{array}{l}\text { CMEP factor; AAbs against } 35-\mathrm{kDa} \text {, } \\
46-\mathrm{kDa}, 30-\mathrm{kDa}, 50-\mathrm{kDa} \text {, and } 70-\mathrm{kDa} \\
\text { proteins; } \alpha-\mathrm{HGF} \text { and HGF }\end{array}$ & Pigment epithelium \\
\hline PON & $\begin{array}{l}\text { adenocarcinoma and small-cell carcinoma of the } \\
\text { lung, prostate carcinoma, stomach carcinoid } \\
\text { tumor, colon adenocarcinoma, cutaneous } \\
\text { melanoma, occult pancreatic nonsecretory } \\
\text { neuroendocrine tumor, thymoma }\end{array}$ & $\begin{array}{l}\text { CRMP5, aquaporin 4, MBP, ANNA-1, } \\
\text { recoverin, enolase }\end{array}$ & $\begin{array}{l}\text { Photoreceptors, ganglion cells, } \\
\text { and their axons }\end{array}$ \\
\hline
\end{tabular}

* Substance (antibody, growth factor, or peptide) that mediates the reaction in the target cell/cells; CAR—cancer-associated retinopathy; CACD—cancer-associated cone dysfunction; PVM—paraneoplastic vitelliform maculopathy; MAR—melanoma-associated retinopathy; BDUMP—bilateral diffuse uveal melanocytic proliferation; PON—paraneoplastic optic neuritis; TULP1—tubby-like protein 1; hsc-70-heat shock cognate protein 70; hsc-60-heat shock cognate protein 60; AIPL1—aryl hydrocarbon receptor interacting protein-like 1; IRBP—interphotoreceptor retinoid binding protein; PNR - photoreceptor cell-specific nuclear receptor; GAPDH—glyceraldehyde 3-phosphate dehydrogenase; GCAPs—guanylyl cyclase-activating proteins; HSP27-heat shock protein 27; Rab6A-Rab6A GTPase; CRMP5—collapsin response mediator protein 5; CA II-carbonic anhydrase II; PRDX3-peroxiredoxin 3 (26-kDa); ROS-rod outer segment protein (120-kDa); TRPM1-transient receptor potential cation channel, subfamily M member 1 (that is labeled on ON-bipolar cells); MLSN1-melastin 1; CMEP factor-cultured melanocyte elongation and proliferation factor; HGF-hepatocytes growth factor; ANNA-1—type 1 antineuronal nuclear antibody; MBP-myelin binding protein. 


\section{Ocular Paraneoplastic Syndromes}

\subsection{Cancer-Associated Retinopathy}

Cancer-associated retinopathy (CAR) is most often a bilateral disease with asymmetric presentation of profound visual loss. The progression rate varies from a few days to several months. In common clinical presentation, it affects both cones and rods. This results in symptoms of cone dysfunction, namely, photosensitivity as well as photopsias (type of visual hallucinations seen as light flashes), prolonged glare, decreased best-corrected visual acuity (BCVA), color discrimination or disturbed color vision, and central scotomas. Rod dysfunction may include night blindness, prolonged adaptation to darkness, and peripheral or ring scotomas [4-18].

Other clinical symptoms include fundus changes. Initially normal fundus can be registered with time periphlebitis and with mild vitritis. Later stages may reveal arteriolar narrowing, retinal pigment epithelial thinning or molting ("salt-and-pepper" appearance), cells in anterior chamber, sheathing of retinal arterioles, and pallor of the optic disc. In optical coherence tomography, loss of outer retinal structures, including ellipsoid and interdigitation zone, can be registered. Fundus autofluorescence (FAF) reveals hyperautofluorescence macular ring area with hypoautofluorescence of the zone outside the macular ring. Fundus fluorescein angiography (FFA) can be normal or may reveal periphlebitis. Central or ring scotomas should be detected in visual field examination. In electroretinography (ERG), rod- and cone-mediated responses are not recordable or significantly decreased, firstly affecting the a-wave and subsequently lining rapidly to a "flat ERG" [8,11-20].

Figure 2 illustrates mechanisms that enable autoantibodies to access retinal targets.

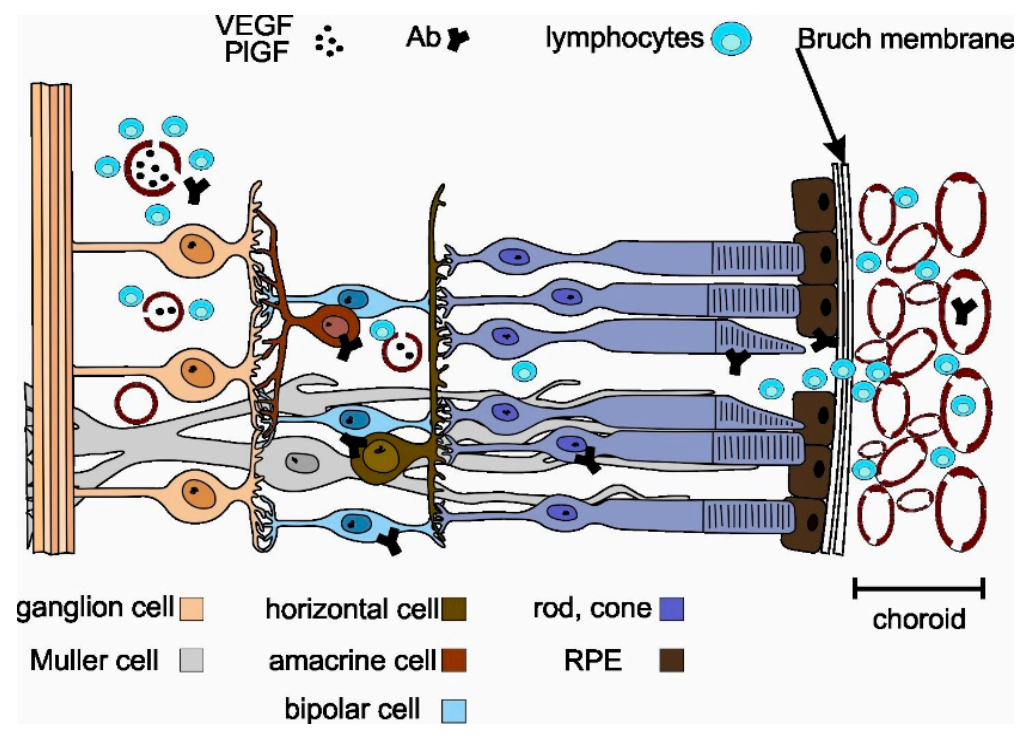

Figure 2. Mechanism of retinal invasion of autoantibodies and lymphocytes during CAR.

The recoverin regulates rhodopsin phosphorylation in a calcium-dependent manner. Mechanisms shown in Figure 2 inhibit normal recoverin function, activate calcium-sensitive endonucleases, degrade caspase substrate Procaspase-3 and Poly (ADP) ribose polymerase (PARP), and fragment DNA. These, in turn, induce apoptosis via the mitochondrial pathway involving the caspase enzymes $[4,7,11,21-23]$. Research on classical complement pathway to evaluate the presence of factors C3 and C9 on photoreceptors and retinal pigment epithelium (RPE) surfaces has found that in normal and affected retinas, the C3 and C9 factors can be seen only in the endothelium of the choroidal blood vessels. Possibly, survival of RPE cells during classical complement pathway activation is due to expression of inhibitory proteins on their surface. Clearly, further research is needed [10].

Some studies have shown that tumor-secreted vascular endothelial growth factor (VEGF) as well as placental growth factor (PlGF) act by the retinal VEGF receptor 1 and induce loss of pericytes within 
the retinal vasculature (breaking the blood-retinal barrier) (shown in Figure 2). CAR-affected retinas show perivascular lymphocytic invasion, normally without or with minimal inflammation [24]. It can be hypothesized that exosome-associated form of CD95L (Fas ligand/FasL), released probably from the two components of the inner blood-retinal barrier (endothelium and retinal pigmented epithelium), may play a crucial role in regulating immune privilege in the eye [25,26]. After initial access due to the vasculitis process, retinal cell damage exacerbates as the RPE damage process spreads via choroidal vasculature (see also Figure 2) [11,27]. Moreover, several works have reported immunomodulatory action by RPE cells. An intriguing study indicated that small RPE-derived exosomes promoted an immunoregulatory phenotype in monocytes [25,28]. Additionally, human RPE cells are known to release from their apical side $\alpha \mathrm{B}$-crystallin in association with exosomes, which is a negative regulator of both innate and cellular immunity [29-31]. All of the functions of RPE described above are restricted during CAR, and this in turn may be key to the exacerbation of photoreceptor damage.

Taking into account the role of RPE in maintaining the eye as an immune-privileged site, the destruction of retinal pigment epithelium can be crucial for exacerbation of antigen-dependent cytotoxic tissue damage during CAR. Additionally, exosomes are responsible for cell surface removal of complementary immune regulators, including CD46, CD55, and CD59 from RPE. The trigger condition is oxidative stress, making RPE cells more vulnerable to complement attack [32]. Cells are able to protect themselves from excessive complement activation by, but not restricted to, cell membrane molecules, such as CD46, CD55, and CD59. CD46 and CD55 regulate the C3 and C5 convertases, and CD59 prevents the formation of C5b-9 complexes [25,32].

Another main autoantigen is alpha-enolase, which is involved in cellular energy production like many other glycolytic enzymes (such as aldolase, glyceraldehyde-3-phosphate dehydrogenase, and pyruvate kinase M2). In this process, the glucose is metabolized to pyruvate in a chain of enzymatic reactions, resulting in production of cellular adenosine triphosphate (ATP). Retina is a very energy-demanding tissue, and in this respect, blocking of the cellular ability to produce ATP by the autoantibodies could be a signal to cell death. The functioning intracellular ATP production pathway is crucial for cell survival [33]. Apart from the function in the glycolytic process, it has been suggested enolase has a role in initiation of a pathological process by modulating the pericellular and intravascular fibrinolytic system. During this process, the enolase is being transferred from the cytoplasm to the cell surface and here serves as a plasminogen receptor that enhances pericellular plasmin production for cell invasion and destruction. Interestingly, the epitopes responsible for plasminogen binding differs significantly from typical pathogenic epitope found in patients with CAR. This suggest that the last mechanism is of low significance in the pathogenesis of CAR [33].

\subsection{Cancer-Associated Cone Dysfunction (CACD)}

Cancer-associated cone dysfunction, a standalone cone dysfunction, is rarely reported. Clinical symptoms originate only from cone dysfunction without any symptoms or electrophysiological signs of rod system failure. Clinical presentation includes mild to moderate BCVA loss, sudden photosensitivity, and total or subtotal loss of color perception. Patients often report improved visual acuity while wearing sunglasses. The ERG shows only cone response suppression [16,34]. According to some researchers, this type of paraneoplastic retinopathy is a subtype of CAR that is caused mainly by antienolase antibodies. Therefore, CACD is presented with overlapping clinical symptoms with CAR as well as other paraneoplastic retinopathies where antienolase antibodies cause retinal tissue damage with or without optic nerve atrophy $[1,35,36]$.

\subsection{Paraneoplastic Vitelliform Maculopathy}

Paraneoplastic vitelliform maculopathy (PVM), also known as acute exudative paraneoplastic polymorphous vitelliform maculopathy (AEPPVM), is a rare bilateral disease. Its clinical presentation may include hemeralopia (decreased visual acuity during the day), blurring, phosphenes, and halos. Symptom duration ranges from a few weeks to several years with asymmetry between eyes [37-41]. 
The fundus examination usually reveals yellow-orange vitelliform lesions that may be accompanied by serous retinal detachment ("pseudo-hypopion" appearance). In optical coherent tomography (OCT) scans, the vitelliform submacular deposits on the pigment epithelium elevate the neurosensory retina. In the fundus, fluorescein angiography lesion is presented with a blocking effect on the choroid. In the late phase, the contrast uptake by lesion is recorded [37,39]. The ERG is usually within normal limits, but some reports indicate aberrant nonspecific findings. On the other hand, the electrooculography (EOG) can indicate a pathological Arden ratio of 1.1, similar to what is elicited in Best disease [1,42].

The pathogenesis is not fully understood. Scarce reports discuss the presence of certain antiretinal and anti-RPE antibodies in peripheral blood samples. It is hypothesized that autoimmune-mediated retinal pigment epitheliopathy occurs, which is based on the presence of antiperoxiredoxin 3 (anti-PRDX3) antibodies. The PRDX3 protein is a mitochondrial peroxidase that is crucial in protection against cellular oxidative damage. Lack of this protection leads to the accumulation of unprocessed cellular debris and (probably) lipofuscin that macroscopically reveals itself as yellowish subretinal deposits [1].

Taking into account the clinical presentation and morphological characteristics, PVM and CACD may be categorized as a group of paraneoplastic retinopathies that affects central vision.

\subsection{Melanoma-Associated Retinopathy}

Melanoma-associated retinopathy (MAR) is a rare condition. In contrast to CAR, with MAR, the neoplasm is already known. MAR is characterized by bilateral presentation with the time-shift between the eyes ranging from weeks to months. Clinical presentations include sudden shimmering, flickering, difficulty with the night vision (nyctalopia), photopsia (pulsating, continuous, or intermittent, often with visual hallucinations), decrease of BCVA (less pronounced than in CAR), sensation of color desaturation or conversely increased contrast (hyperphotosensitivity), and bilateral peripheral vision loss [41,43-45]. Progression occurs usually over a few weeks to months but, in rare cases, may be sudden. Usually, eye fundus examination is normal in the majority of cases. In the most advanced cases, signs similar to CAR may be observed, namely, disc pallor, attenuated vascular reflexes, zones of retinal pigment epithelial atrophy ("salt-and-paper"), and vitritis accompanied by vasculitis. OCT scans often present macular atrophy with thinning of the inner retina. Fundus fluorescence angiography is usually normal or, in cases of vasculitis, show vascular diffusion. Typical ERG readings are observed, such as disappearance or microvoltage of b-waves while a-waves remain normal in scotopic conditions. In addition, there may be significant dysfunction of bipolar cells with preservation of photoreceptor function. In some studies, a mild reduction of both a-wave and b-wave amplitudes for both scotopic and photopic waveform dependent systems dysfunction. In EOG, the retinal pigment epithelium dysfunction can be evaluated by a reduced Arden ratio [41,43-47].

MAR is defined by three classical characteristics: (1) symptoms of night blindness (nyctalopia) with positive visual phenomena or visual field defects; (2) reduction in b-wave amplitude in ERG; and (3) presence of serum autoantibodies that are reactive with retinal bipolar cells [43].

\subsection{Bilateral Diffuse Uveal Melanocytic Proliferation (BDUMP)}

Bilateral diffuse uveal melanocytic proliferation is a very rare paraneoplastic syndrome characterized by benign proliferation of uveal tract melanocytes. The bilateral visual loss can be profound and rapidly progressive. Patients with BDUMP experience slow, painless, bilateral (in most cases asymmetric), progressive loss of vision over several months. BCVA can also deteriorate due to secondary causes, such as cataract, glaucoma, or iridocyclitis [48-60]. The proliferation of melanocytes results in subretinal infiltration and an exudative retinal detachment (an outer retinal damage). Fundus examination presents with multiple, bilateral round or oval red (dark) spots or patches at the level of pigment epithelium that can be usually found in the posterior pole. The examiner should perform detailed examination of the peripheral fundus and the peripheral arterial nonperfusion area. Nummular or dermal loss of retinal pigment epithelium in FFA and funduscopy can be found. 
In the slit-lamp examination, the iris nodules, pigmented keratic precipitates, anterior chamber, and vitreous cells can be observed. In some cases, conjunctival melanocytic proliferation occurs. Hypo- or hyperautofluorescence characteristic "giraffe-like" pattern lesions can be seen during FAF examination. Similar multifocal hyperfluorescence may be revealed during fluorescein angiography in corresponding lesions. Additionally, exudative retinal detachment occurs in the later phases of FFA. Moreover, in OCT, a diffuse thickening of the uveal tract with multiple elevated pigment and nonpigment uveal melanocytic tumors can be recorded. Deep scans in OCT reveal possible atrophy of the choroidal vasculature, which has to be differentiated from age-related macular dystrophy. There are no specific ERG symptoms. The reduction of scotopic and photopic a- and b-wave amplitude can be observed [48-58,61,62].

Pathophysiologically, there are two main causes of this type of paraneoplastic changes: (1) production of melanocytic growth factors by tumor cells with subsequent release into the circulation and (2) antiretinal autoantibodies (suggested anti- $\alpha$ - hepatocyte growth factor (HGF)) in circulation. The impact of the antiretinal autoantibodies appears to be rare compared to that of growth factors. The known and previously isolated IgG antibody is named cultured melanocyte elongation and proliferation factor (CMEP). In addition, the HGF has been suggested [1,57,61,62]. The damage in the RPE layer results in outer blood-retina dysfunction due to RPE malfunctions, and antiretinal autoantigens can subsequently invade the subretinal space $[48,57,61]$.

\subsection{Paraneoplastic Optic Neuropathy}

Paraneoplastic optic neuropathies (PON) are rarer compared to other retinopathies. Classical clinical characteristic of PON include painless, progressive (ranging from days to weeks), bilateral BCVA loss or visual field sensitivity deterioration caused mainly by loss of neural retina (retinal ganglion cells and their axons). Funduscopic evaluation reveals changes in the optic nerve head, such as pallor, hypermia, edema, or local dropout of retinal nerve fiber layer (RNFL) [63-75].

\section{Ancillary Tests}

The following antibodies should be included in the evaluation of OPNS: antirecoverin, antienolase, anti-GAPDH, and antitransducin. There are several well-known mechanisms of action of these autoantibodies.

Antirecoverin antibodies act in the mechanism of apoptosis mediated by caspase-dependent pathways along with intracellular calcium influx [11,21-23,76]. The main destructive effects are directed to the photoreceptors [1].

Antienolase antibodies appear to act via similar mechanism as antirecoverin, but this conjecture needs further investigation [22,36]. The alpha-enolase is engaged in the process of glycolysis in retinal photoreceptors and some other cells within retinal tissue (e.g., Muller cells). The enolase is one of the most common autoantigens. Additionally, it has been reported in several systemic autoimmune, connective tissue and inflammatory disorders, such as Behcet disease, Hashimoto's encephalopathy, associated antineutrophil cytoplasmic antibody (ANCA)-positive vasculitis, rheumatoid arthritis, systemic lupus erythematosus, multiple sclerosis, primary sclerosing cholangitis, and inflammatory bowel disease [33]. Antienolase antibody appears to target the ganglion cells and inner retinal layers [1].

The tubby-like protein 1 (TULIP1) is characteristic of the rods and cones, participating in normal transport during phototransduction proteins. Anti-TULIP1 antibodies interrupt the phototransduction process, and this leads to accumulation of metabolic products [22].

GAPDH is involved in energy metabolism, cell signaling, and synaptic neurotransmission. Anti-GAPDH antibodies appear to contribute to cell damage due to inhibition of membrane fusion, vesicle transportation, or activation of transcription. The GAPDH also plays a role in the processes of apoptosis and oxidative stress, which are other possible mechanisms by which aberrant functions can lead to cell destruction [22,23]. Antitransducin antibody is focused on the outer and inner segments of photoreceptors as well as the cytoplasm of ganglion cells $[1,77,78]$. 
Multimodal imaging is critical to diagnosis [79] along with antiretinal antibody testing for diagnosis and treatment. However, the Ocular Immunology Laboratory in USA offers standard procedures for antibody testing and serves clinicians around a world to help them with diagnosis and to monitor treatment (https://www.ohsu.edu/casey-eye-institute/ocular-immunology-lab). The clinician should include fundus photography, OCT with choroid visualization, FFA, FAF, ERG, and multifocal ERG (mf ERG). However, there is no reliable research available on large scale studies for multimodal imaging. There is a great need to conduct a multicenter large data analysis that will include all additional modalities in clinical presentation, such as OCT, FFA, FAF, indocyanine green angiography, and others.

During the past few decades, a wide range of autoantibodies and molecular markers of OPNS have been proposed and evaluated (Table 3 presents a comprehensive list). Unfortunately, many of them have overlapping characteristic as described above, and the visual system appears to be normal in some cases [80]. The evaluation of molecular markers may aid in the diagnosis of an OPNS. However, this is not an absolute requirement since, certain autoantibodies, growth factors, and other molecules are produced in the absence of PNS.

\subsection{Antiretinal Antibodies}

There are auto-anti-retinal proteins associated with visual symptoms and structural disturbances of retina in paraneoplastic and nonparaneoplastic autoimmune retinopathies [20]. Interestingly, there are some similarities in the clinical presentation of retinopathy associated with specific autoantibodies.

In 2018, Adamus [20] indicated that there was a clinical phenotype for antirecoverin-associated retinopathy that is different from antienolase-associated changes. Differences include onset, ocular symmetry, and clinical presentation, as well as prognosis of the best corrected visual acuity and electrophysiological changes. In some cases, the autoantibodies are strongly associated with specific cancer and precedes its diagnosis. The clinical presentations also vary with respect to the number of cells affected. There is probably a critical number of cells that have to be destroyed before the symptoms are revealed; if the number of cells is below the threshold count, clinical evidence is obscured by the plasticity of retinal neuronal network or by the "filling-in" phenomenon of the whole visual system. Moreover, there are some similarities between hereditary retinitis and autoimmunological background, such as retinitis pigmentosa $[22,24,35,77,81,82]$.

Retinal phenotypes based on the seropositivity comprise the following:

\section{(A) Antirecoverin}

Average age of onset is over 60 years, and patients are predominately female (female/male ratio $=2: 1$ ). This entry is highly symmetric, with acute (sudden) unexplained onset. Patient complaints are usually focused on photopsia, nyctalopia, and photophobia. Main presentation is severe central and peripheral vision loss, sometimes described as "ring scotoma". During the course of the disease, rapid rod and cone loss is seen, often with vision acuity reduced to light perception or to no light perception in some cases. The ffERG is useful since there is a severe decrease in response of rods and cones, in addition to abnormal multifocal ERG $[7,20,22,83]$.

(B) Antienolase

Antienolase antibodies are associated with a subacute or even chronic presentation that is often symmetric. There is a variable central and global visual field loss with gradual and variable rate of visual acuity loss. Usually, the best corrected visual acuity is no better than 20/300 after several years of onset. There is characteristic nonequal dysfunction in cone and rod responses in ERG. The cones are more damaged than the rods with mild to severe abnormal mfERG $[22,36,63]$.

(C) Antitransducin

This is characterized as sudden but slowly progressive, symmetric, mild, patchy to global visual field loss with visual acuity loss secondary to the visual field symptoms. In electroretinography, 
primary scotopic defect (rod function) is found, and in mfERG, both decreased amplitudes and delayed timing is seen $[22,77,84]$.

(D) Anti-CAII

This is usually a subacute, chronic, often symmetric presentation of paraneoplastic retinopathy with mild vitritis and mild to severe concentric constriction of visual field that occurs with color and visual acuity loss. In ERG, slight subnormal rod response can be found, but mfERG is of little use as it varies significantly from case to case $[5,22,85]$.

(E) Anti-Rab6

The average age of onset is around 60 years, and patients are predominately female (female/male ratio $=2: 1$ ). Onset is sudden and often symmetric. Main patient complaints are photopsia and nyctalopia. Central and peripheral visual field loss can be found. In full-field ERG, the response of rods and cones are decreased, and severely abnormal mfERG can be found (which can progress over weeks to months) [7].

(F) Anti-HSP27

This is a type of paraneoplastic retinopathy that occurs in patients around 60 years of age with strong predominance of females over males (females/males $=3: 1$ ). Its characteristic can be described as subacute, slowly progressive, and mostly symmetric. Patient complaints are mostly focused on photopsia and nyctalopia with constriction of visual field, occurrence of central scotoma, or enlargement of blind spot. In ERG, generalized loss of response of rods and cones can be recorded [7].

(G) Anti-GCAP1

The anti-GCAP1 retinopathy occurs equally in males and females. Its onset can be characterized as subacute, chronic, and symmetric. The main patient complaint is photophobia. In additional tests, maculopathy can be seen with loss of color vision and visual acuity. Progressive cone loss with gradual cone dysfunction is characteristic in ERG [7].

There are three possible causes of autoretinal antibody formation: (a) immunological response to the tumor; (b) immunological response to the microbiome of infection, including an asymptomatic infection that can trigger antibody formation in susceptible subjects due to conformational mimicry of antigens; and (c) autoimmunological response to the self-antigens that are first sequestrated and separated from the immune system and later released by the damaged retina $[24,35,81]$.

The concept of the eye as an immune-privileged site is widely accepted, although its exact mechanisms is not completely understood. It is also known that the phenomenon is not absolute. Retina-specific $\mathrm{T}$ cells that are primed for effector function strongly resist conversion to suppressive $\mathrm{T}$ regulatory cells (before site-specific local antigen recognition). It is possible that T-effective cells can overcome the immunosuppressive ocular microenvironment to cause primary retinal tissue damage. Considering this scenario, antiretinal antibodies could be secondary causes of retinopathy. More research is needed to distinguish if cellular-rather than humoral-response is responsible for primary retinal tissue damage in paraneoplastic retinopathies [21,24,86-88].

\subsection{Tumor-Expressed Growth Factors}

There are known mechanisms of action of different growth factors in paraneoplastic ocular syndrome development. The CMEP factor promotes RPE growth and melanocytic proliferation in the subretinal space. This, in turn, causes disruption of the outer blood-retinal barrier by RPE malfunction $[1,48,61]$. HGF, probably by prolonged high-level stimulation of this growth factor, combined with retinal autoantibodies may drive choroidal nevis growth and RPE damage [57]. VEGF and PIGF play roles in the reduction of endothelial cells in the retinal macrophages and lymphocytes 
to invade the retina. The described mechanism depends on damage to or destruction of tight junctions between endothelial cells that cause dysfunction of the inner blood-retina barrier [24].

\section{Possible Role of Extracellular Vesicles (EVs) in the Development of Paraneoplastic Syndromes}

Recently, the concept of the association between paraneoplastic syndromes and extracellular vesicles has emerged. The term EV encompasses exosomes, microvesicles, and apoptotic bodies [89]. EVs enable communication between cancer cells and other organs in the body [90]. For at least the past decade, exosomes have been considered as a factor that plays a potential role in the development of paraneoplastic syndromes [91], mostly in cancers other than those developing in the eye [91-93]. Usually, PNS occur when immune-mediated cross-reactivity activates tumor antigens, resulting in damage to normal host tissues. There are PNS that seem to be caused by the ectopic production of a hormone or a growth factor that acts at a great distance from the production site. The exact pathophysiologic mechanisms that contribute to breaking the eye immune privilege, enabling the occurrence of OPNS, have not been precisely described. Although not conclusive, it can be hypothesized that EVs participate in the onset and progression of OPNS.

Supplementary Materials: The following are available online at http:/www.mdpi.com/2227-9059/8/11/490/s1.

Author Contributions: G.A. analyzed and interpreted the data, wrote the manuscript, and approved the final version of the manuscript. J.P.-D., A.B., M.E., M.M.-H., L.F.T.S., A.S.H., S.G.S., C.E.K., and G.A. reviewed and edited the manuscript. All authors have read and agreed to the final version of the manuscript.

Funding: This research was funded by Russian Academic Excellence project "5-100" for Sechenov University, Moscow, Russia; GALLY International Research Institute, San Antonio, Texas, USA; and Human Photosynthesis Study Center, Aguascalientes, México.

Conflicts of Interest: The authors declare no conflict of interest.

$\begin{array}{ll}\text { Abbreviations } \\ \text { AAbs } & \text { autoantibodies } \\ \text { AIPL1 } & \text { aryl hydrocarbon receptor interacting protein-like 1 } \\ \text { ANNA-1 } & \text { type 1 antineuronal nuclear antibody } \\ \text { BCVA } & \text { best-corrected visual acuity } \\ \text { BDUMP } & \text { bilateral diffuse uveal melanocytic proliferation } \\ \text { CA II } & \text { carbonic anhydrase II } \\ \text { CACD } & \text { cancer-associated cone dysfunction } \\ \text { CAR } & \text { cancer-associated retinopathy } \\ \text { CMEP factor } & \text { cultured melanocyte elongation and proliferation factor } \\ \text { CRMP5 } & \text { collapsin response mediator protein 5 } \\ \text { EOG } & \text { electrooculography } \\ \text { ERG } & \text { electroretinography } \\ \text { FAF } & \text { fundus autofluorescence } \\ \text { FFA } & \text { fundus fluorescein angiography } \\ \text { GAPDH } & \text { glyceraldehyde 3-phosphate dehydrogenase } \\ \text { GCAPs } & \text { guanylyl cyclase-activating proteins } \\ \text { hsc-70 } & \text { heat shock cognate protein 70 } \\ \text { hsc-60 } & \text { heat shock cognate protein 60 } \\ \text { HSP27 } & \text { heat shock protein 27 } \\ \text { IRBP } & \text { interphotoreceptor retinoid binding protein } \\ \text { MAR } & \text { melanoma-associated retinopathy } \\ \text { MBP } & \text { myelin binding protein } \\ \text { MLSN1 } & \text { melastin 1 }\end{array}$




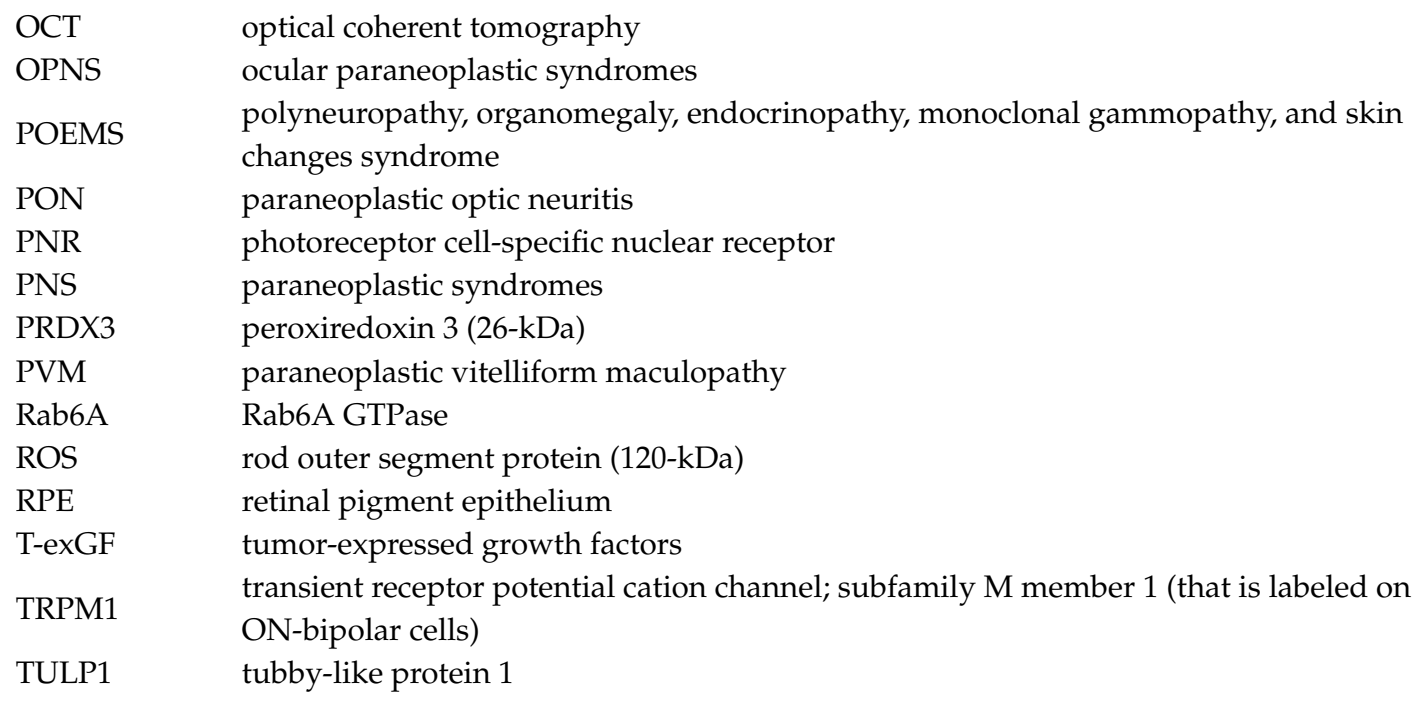

\section{References}

1. Rahimy, E.; Sarraf, D. Paraneoplastic and non-paraneoplastic retinopathy and optic neuropathy: Evaluation and management. Surv. Ophthalmol. 2013, 58, 430-458. [CrossRef] [PubMed]

2. Darnell, R.B.; Posner, J.B. Paraneoplastic syndromes involving the nervous system. N. Engl. J. Med. 2003, 349, 1543-1554. [CrossRef] [PubMed]

3. De Salvo, G.; Prakash, P.; Rennie, C.A.; Lotery, A.J. Long-term survival in a case of bilateral diffuse uveal melanocytic proliferation. Eye 2011, 25, 1385-1386. [CrossRef]

4. Adamus, G. Latest updates on antiretinal autoantibodies associated with vision loss and breast cancer. Investig. Ophthalmol. Vis. Sci. 2015, 56, 1680-1688. [CrossRef] [PubMed]

5. Dalin, F.; Adamus, G.; Yang, S.; Landgren, E.; Palle, J.; Hallgren, Å.; Frost, B.-M.; Hugosson, T.; Landegren, N.; Eriksson, D.; et al. Aryl Hydrocarbon Receptor-Interacting Protein-Like 1 in Cancer-Associated Retinopathy. Ophthalmology 2016, 123, 1401-1404. [CrossRef]

6. Weixler, B.; Oertli, D.; Nebiker, C.A. Cancer-associated retinopathy as the leading symptom in colon cancer. Clin. Case Rep. 2016, 4, 171-176. [CrossRef]

7. Yang, S.; Dizhoor, A.; Wilson, D.J.; Adamus, G. GCAP1, Rab6, and HSP27: Novel Autoantibody Targets in Cancer-Associated Retinopathy and Autoimmune Retinopathy. Transl. Vis. Sci. Technol. 2016, 5, 1. [CrossRef]

8. Yagyu, K.; Ueda, T.; Miyamoto, A.; Uenishi, R.; Matsushita, H.; Tanaka, T. Cancer-associated Retinopathy with Neuroendocrine Combined Large-cell Lung Carcinoma and Adenocarcinoma. Intern. Med. 2019, 58, 3289-3294. [CrossRef]

9. Ramos-Ruperto, L.; Busca-Arenzana, C.; Boto-de Los Bueis, A.; Schlincker, A.; Arnalich-Fernández, F.; Robles-Marhuenda, Á. Cancer-Associated Retinopathy and Treatment with Intravenous Immunoglobulin Therapy. A Seldom Used Approach? Ocul. Immunol. Inflamm. 2019, 1-4. [CrossRef]

10. Dryja, T.P.; Demirs, J.T.; Twarog, M.; Lee, V. Complement Proteins in the Retina in Cancer-Associated Retinopathy. JAMA Ophthalmol. 2019. [CrossRef]

11. Carrera, W.; Tsamis, K.A.; Shah, R. A case of cancer-associated retinopathy with chorioretinitis and optic neuritis associated with occult small cell lung cancer. BMC Ophthalmol. 2019, 19, 101. [CrossRef] [PubMed]

12. Naramala, S.; Ahmad, J.; Adapa, S.; Gavini, F.; Konala, V.M. Case Series of Cancer-associated Retinopathy (CAR). Cureus 2019, 11, e4872. [CrossRef] [PubMed]

13. Ghadiri, N.; Yang, Y.; Burton, B.J. Cancer-associated retinopathy in ampullary pancreatic cancer. BMJ Case Rep. 2019, 12. [CrossRef] [PubMed]

14. Kamei, M.; Fujitomi, Y.; Kondo, Y.; Adachi, T.; Shibata, K.; Takumi, Y.; Abe, M.; Sugio, K. Cancer-associated retinopathy after surgery for breast cancer: A case report and review of the literature. Surg. Case Rep. 2018, 4, 10. [CrossRef] [PubMed]

15. Igarashi, N.; Sawamura, H.; Kaburaki, T.; Aihara, M. Cancer-associated Retinopathy Developing After 10 Years of Complete Breast Cancer Remission. Neuroophthalmology 2019, 43, 36-42. [CrossRef] 
16. Javaid, Z.; Rehan, S.M.; Al-Bermani, A.; Payne, G. Unilateral cancer-associated retinopathy: A case report. Scott. Med. J. 2015. [CrossRef]

17. Roels, D.; Ueno, S.; Talianu, C.D.; Draganova, D.; Kondo, M.; Leroy, B.P. Unilateral cancer-associated retinopathy: diagnosis, serology and treatment. Doc. Ophthalmol. 2017, 135, 233-240. [CrossRef]

18. Hoogewoud, F.; Butori, P.; Blanche, P.; Brézin, A.P. Cancer-associated retinopathy preceding the diagnosis of cancer. BMC Ophthalmol. 2018, 18, 285. [CrossRef]

19. Makiyama, Y.; Kikuchi, T.; Otani, A.; Oishi, A.; Guo, C.; Nakagawa, S.; Ogino, K.; Kojima, H.; Kurimoto, M.; Yoshimura, N. Clinical and immunological characterization of paraneoplastic retinopathy. Investig. Ophthalmol. Vis. Sci. 2013, 54, 5424-5431. [CrossRef]

20. Stanwyck, L.K.; Chan, W.; Sood, A.; Susarla, G.; Romano, J.; Pefkianaki, M.; Jayasundera, K.T.; Heckenlively, J.R.; Lundy, S.K.; Sobrin, L. Correlation of Immunological Markers with Disease and Clinical Outcome Measures in Patients with Autoimmune Retinopathy. Transl. Vis. Sci. Technol. 2020, 9. [CrossRef]

21. Braithwaite, T.; Vugler, A.; Tufail, A. Autoimmune Retinopathy. OPH 2012, 228, 131-142. [CrossRef] [PubMed]

22. Grewal, D.S.; Fishman, G.A.; Jampol, L.M. Autoimmune retinopathy and antiretinal antibodies: A review. Retina 2014, 34, 827-845. [CrossRef] [PubMed]

23. Adamus, G.; Brown, L.; Schiffman, J.; Iannaccone, A. Diversity in autoimmunity against retinal, neuronal, and axonal antigens in acquired neuro-retinopathy. J. Ophthalmic Inflamm. Infect. 2011, 1, 111-121. [CrossRef] [PubMed]

24. Adamus, G. Are Anti-Retinal Autoantibodies a Cause or a Consequence of Retinal Degeneration in Autoimmune Retinopathies? Front. Immunol. 2018, 9, 765. [CrossRef]

25. Klingeborn, M.; Dismuke, W.M.; Rickman, C.B.; Stamer, W.D. Roles of Exosomes in the Normal and Diseased Eye. Prog. Retin. Eye Res. 2017, 59, 158-177. [CrossRef]

26. Perez, V.L.; Caspi, R.R. Immune mechanisms in inflammatory and degenerative eye disease. Trends Immunol. 2015, 36, 354-363. [CrossRef]

27. Cao, R.; Cao, Y. Cancer-associated retinopathy: A new mechanistic insight on vascular remodeling. Cell Cycle 2010, 9, 1882-1885. [CrossRef]

28. Knickelbein, J.E.; Liu, B.; Arakelyan, A.; Zicari, S.; Hannes, S.; Chen, P.; Li, Z.; Grivel, J.-C.; Chaigne-Delalande, B.; Sen, H.N.; et al. Modulation of Immune Responses by Extracellular Vesicles From Retinal Pigment Epithelium. Investig. Ophthalmol. Vis. Sci. 2016, 57, 4101-4107. [CrossRef]

29. Gangalum, R.K.; Atanasov, I.C.; Zhou, Z.H.; Bhat, S.P. AlphaB-crystallin is found in detergent-resistant membrane microdomains and is secreted via exosomes from human retinal pigment epithelial cells. J. Biol. Chem. 2011, 286, 3261-3269. [CrossRef] [PubMed]

30. Ousman, S.S.; Tomooka, B.H.; Van Noort, J.M.; Wawrousek, E.F.; O'Conner, K.; Hafler, D.A.; Sobel, R.A.; Robinson, W.H.; Steinman, L. Protective and therapeutic role for alphaB-crystallin in autoimmune demyelination. Nature 2007, 448, 474-479. [CrossRef]

31. Sreekumar, P.G.; Kannan, R.; Kitamura, M.; Spee, C.; Barron, E.; Ryan, S.J.; Hinton, D.R. $\alpha$ B crystallin is apically secreted within exosomes by polarized human retinal pigment epithelium and provides neuroprotection to adjacent cells. PLoS ONE 2010, 5, e12578. [CrossRef] [PubMed]

32. Ebrahimi, K.B.; Fijalkowski, N.; Cano, M.; Handa, J.T. Decreased membrane complement regulators in the retinal pigmented epithelium contributes to age-related macular degeneration. J. Pathol. 2013, 229, 729-742. [CrossRef] [PubMed]

33. Adamus, G. Impact of Autoantibodies against Glycolytic Enzymes on Pathogenicity of Autoimmune Retinopathy and Other Autoimmune Disorders. Front. Immunol. 2017, 8. [CrossRef] [PubMed]

34. Mrejen, S.; Audo, I.; Bonnel, S.; Sahel, J.-A. Retinitis Pigmentosa and Other Dystrophies. Dev. Ophthalmol. 2017, 58, 191-201. [CrossRef] [PubMed]

35. Weleber, R.G.; Watzke, R.C.; Shults, W.T.; Trzupek, K.M.; Heckenlively, J.R.; Egan, R.A.; Adamus, G. Clinical and electrophysiologic characterization of paraneoplastic and autoimmune retinopathies associated with antienolase antibodies. Am. J. Ophthalmol. 2005, 139, 780-794. [CrossRef]

36. Magrys, A.; Anekonda, T.; Ren, G.; Adamus, G. The role of anti-alpha-enolase autoantibodies in pathogenicity of autoimmune-mediated retinopathy. J. Clin. Immunol. 2007, 27, 181-192. [CrossRef] 
37. Li, D.Q.; Golding, J.; Glittenberg, C.; Choudhry, N. Multimodal Imaging Features in Acute Exudative Paraneoplastic Polymorphous Vitelliform Maculopathy. Ophthalmic Surg. Lasers Imaging Retina 2016, 47, 1143-1146. [CrossRef]

38. Murtagh, P.; Treacy, M.; Stephenson, K.; Dooley, I. Acute Exudative Polymorphous Vitelliform Maculopathy Syndrome; natural history and evolution of fundal and OCT images over time. BMJ Case Rep. 2018, 2018. [CrossRef]

39. Gündüz, K.; Çöndü, G.; Shields, C.L. Acute Exudative Polymorphous Paraneoplastic Vitelliform Maculopathy Managed With Intravitreal Aflibercept. Ophthalmic Surg. Lasers Imaging Retina 2017, 48, 844-850. [CrossRef]

40. Barbazetto, I.; Dansingani, K.K.; Dolz-Marco, R.; Giovannini, A.; Piccolino, F.C.; Agarwal, A.; Lima, L.H.; Vianna, R.N.; Yannuzzi, L.A. Idiopathic Acute Exudative Polymorphous Vitelliform Maculopathy: Clinical Spectrum and Multimodal Imaging Characteristics. Ophthalmology 2018, 125, 75-88. [CrossRef]

41. Lincoff, N.; Nadeem, M.; Younus, Z.; Thirkill, C.E. Exudative Polymorphous Vitelliform Retinopathy: Importance of Early Recognition of the Condition in Patients with Metastatic Melanoma. Ophthalmol. Ther. 2016, 5, 121-127. [CrossRef]

42. Eksandh, L.; Adamus, G.; Mosgrove, L.; Andréasson, S. Autoantibodies against bestrophin in a patient with vitelliform paraneoplastic retinopathy and a metastatic choroidal malignant melanoma. JAMA Ophthalmol. 2008, 126, 432-435. [CrossRef] [PubMed]

43. Elsheikh, S.; Gurney, S.P.; Burdon, M.A. Melanoma-associated retinopathy. Clin. Exp. Dermatol. 2020, 45, 147-152. [CrossRef]

44. Heberton, M.; Azher, T.; Council, M.L.; Khanna, S. Metastatic Cutaneous Melanoma Presenting With Melanoma-Associated Retinopathy. Dermatol. Surg. 2019, 45, 606-607. [CrossRef] [PubMed]

45. Tian, J.J.; Coupland, S.; Karanjia, R.; Sadun, A.A. Melanoma-Associated Retinopathy 28 Years After Diagnosis. JAMA Ophthalmol. 2017, 135, 1276-1277. [CrossRef] [PubMed]

46. Aronow, M.E.; Adamus, G.; Abu-Asab, M.; Wang, Y.; Chan, C.-C.; Zakov, Z.N.; Singh, A.D. Paraneoplastic vitelliform retinopathy: Clinicopathologic correlation and review of the literature. Surv. Ophthalmol. 2012, 57, 558-564. [CrossRef]

47. Varin, J.; Reynolds, M.M.; Bouzidi, N.; Tick, S.; Wohlschlegel, J.; Becquart, O.; Michiels, C.; Dereure, O.; Duvoisin, R.M.; Morgans, C.W.; et al. Identification and characterization of novel TRPM1 autoantibodies from serum of patients with melanoma-associated retinopathy. PLoS ONE 2020, 15. [CrossRef] [PubMed]

48. Mittal, R.; Cherepanoff, S.; Thornton, S.; Kalirai, H.; Damato, B.; Coupland, S.E. Bilateral Diffuse Uveal Melanocytic Proliferation: Molecular Genetic Analysis of a Case and Review of the Literature. Ocul. Oncol. Pathol. 2015, 2, 94-99. [CrossRef] [PubMed]

49. Jansen, J.C.G.; Van Calster, J.; Pulido, J.S.; Miles, S.L.; Vile, R.G.; Van Bergen, T.; Cassiman, C.; Spielberg, L.H.; Leys, A.M. Early diagnosis and successful treatment of paraneoplastic melanocytic proliferation. Br. J. Ophthalmol. 2015, 99, 943-948. [CrossRef]

50. Padrón-Pérez, N.; Caminal, J.M.; Lorenzo, D.; Català-Mora, J. Bilateral multiple iridociliary cysts in diffuse uveal melanocytic proliferation. Can. J. Ophthalmol. 2017, 52, e225-e228. [CrossRef]

51. van Noort, B.C.; Keunen, J.E.E.; Schlingemann, R.O.; Marinkovic, M. Long Survival and Preservation of Good Visual Acuity in a Patient with Bilateral Diffuse Uveal Melanocytic Proliferation. Ocul. Oncol. Pathol. 2019, 5, 75-78. [CrossRef] [PubMed]

52. Lavine, J.A.; Ramos, M.S.; Wolk, A.M.; Baynes, K.; Sharma, S.; Rachitskaya, A.V.; Anand-Apte, B.; Srivastava, S.K.; Yuan, A. Heterogeneity of cultured melanocyte elongation and proliferation factor in bilateral diffuse uveal melanocytic proliferation. Exp. Eye Res. 2019, 184, 30-37. [CrossRef] [PubMed]

53. Raval, V.; Pathengay, A.; Narayanan, R. Bilateral diffuse uveal melanocytic proliferation secondary to thyroid carcinoma. Indian J. Ophthalmol. 2019, 67, 2094-2097. [CrossRef] [PubMed]

54. Spaide, R.F. Unilateral diffuse uveal melanocytic proliferation. Retin. Cases Brief Rep. 2018, 12, $263-265$. [CrossRef] [PubMed]

55. Shiraki, A.; Winegarner, A.; Hashida, N.; Nishi, O.; Nishi, Y.; Maruyama, K.; Nishida, K. Diagnostic evaluation of optical coherence tomography angiography and fundus autofluorescence in bilateral diffuse uveal melanocytic proliferation. Am. J. Ophthalmol. Case Rep. 2018, 11, 32-34. [CrossRef]

56. Alasil, T.; Coady, P.A.; Koudsi, S.; Mathur, M.; Materin, M.A. Bilateral diffuse uveal melanocytic proliferation: A case report. Retin. Cases Brief Rep. 2017, 11, 71-74. [CrossRef] 
57. Niffenegger, J.H.; Soltero, A.; Niffenegger, J.S.; Yang, S.; Adamus, G. Prevalence of Hepatocyte Growth Factor and Autoantibodies to $\alpha$-HGF as a New Etiology for Bilateral Diffuse Uveal Melanocytic Proliferation Masquerading as Neovascular Age-Related Macular Degeneration. J. Clin. Exp. Ophthalmol. 2018, 9. [CrossRef] [PubMed]

58. Kniggendorf, V.F.; Neto, E.T.; Maia, E.M.; Grando, J.P.S.; Bardal, A.M.C.; Beato, P.M.M.; Torres, C.C.; Maia, M. Bilateral diffuse uveal melanocytic proliferation associated with renal cancer: The importance of indocyanine green angiography and early diagnosis. Retin. Cases Brief Rep. 2018, 12, 166-171. [CrossRef] [PubMed]

59. Dolz-Marco, R.; Vilaplana, F.; Gallego-Pinazo, R.; Freund, K.B. Delayed-onset bilateral diffuse uveal melanocytic proliferation associated with gastric adenocarcinoma. Retin. Cases Brief Rep. 2017, 11 (Suppl. 1), S182-S186. [CrossRef]

60. Tanaka, M.; Kamoi, K.; Nagaoka, N.; Ishida, T.; Karube, H.; Takase, H.; Ohno-Matsui, K. Bilateral diffuse retinal pigment epithelium proliferation induced by choroidal inflammation. Medicine 2019, 98. [CrossRef] [PubMed]

61. Rahimy, E.; Coffee, R.E.; McCannel, T.A. Bilateral diffuse uveal melanocytic proliferation as a precursor to multiple systemic malignancies. Semin. Ophthalmol. 2015, 30, 206-209. [CrossRef] [PubMed]

62. Luo, M.; Chen, Z.; Luo, Y.; Zhao, L.; Dai, R.; Zhong, Y. Diagnosis of bilateral diffuse uveal melanocytic proliferation unveils primary gastric adenocarcinoma: A case report. BMC Ophthalmol. 2020, 20. [CrossRef] [PubMed]

63. Saito, M.; Saito, W.; Kanda, A.; Ohguro, H.; Ishida, S. A case of paraneoplastic optic neuropathy and outer retinitis positive for autoantibodies against collapsin response mediator protein-5, recoverin, and $\alpha$-enolase. BMC Ophthalmol. 2014, 14, 5. [CrossRef] [PubMed]

64. Yang, H.K.; Woo, S.J.; Park, W.-Y.; Hwang, J.-M. Paraneoplastic neuromyelitis optica associated with ANNA-1 antibodies in invasive thymoma. BMC Ophthalmol. 2014, 14, 106. [CrossRef] [PubMed]

65. Figueroa, M.; Guo, Y.; Tselis, A.; Pittock, S.J.; Lennon, V.A.; Lucchinetti, C.F.; Lisak, R.P. Paraneoplastic neuromyelitis optica spectrum disorder associated with metastatic carcinoid expressing aquaporin-4. JAMA Neurol. 2014, 71, 495-498. [CrossRef] [PubMed]

66. Iyer, A.; Elsone, L.; Appleton, R.; Jacob, A. A review of the current literature and a guide to the early diagnosis of autoimmune disorders associated with neuromyelitis optica. Autoimmunity 2014, 47, 154-161. [CrossRef] [PubMed]

67. Verschuur, C.V.M.; van der Kooi, A.J.; Troost, D. Anti-aquaporin 4 related paraneoplastic neuromyelitis optica in the presence of adenocarcinoma of the lung. Clin. Neuropathol. 2015, 34, 232-236. [CrossRef] [PubMed]

68. Al-Harbi, T.; Al-Sarawi, A.; Binfalah, M.; Dermime, S. Paraneoplastic neuromyelitis optica spectrum disorder associated with stomach carcinoid tumor. Hematol. Oncol. Stem Cell Ther. 2014, 7, 116-119. [CrossRef]

69. Dubey, D.; Lennon, V.A.; Gadoth, A.; Pittock, S.J.; Flanagan, E.P.; Schmeling, J.E.; McKeon, A.; Klein, C.J. Autoimmune CRMP5 neuropathy phenotype and outcome defined from 105 cases. Neurology 2018, 90, e103-e110. [CrossRef]

70. Durrani, A.; Shah, R.J.; Kim, S.J. Successful long-term treatment of paraneoplastic optic neuropathy with mycophenolate mofetil, prednisone, and plasmapheresis. Am. J. Ophthalmol. Case Rep. 2017, 8, 31-34. [CrossRef]

71. Micieli, J.A.; Margolin, E.A. Paraneoplastic Optic Neuropathy Associated With Purkinje Cell Antibody-2 in a Patient With Small Cell Lung Cancer. J. Neuroophthalmol. 2017, 37, 53-55. [CrossRef] [PubMed]

72. Shukla, S.Y.; Pula, J.H.; Khan, S.; Lee, J.M. Paraneoplastic Optic Neuropathy and Pineal Germinoma With Collapsin Response-Mediating Protein Antibodies. J. Neuroophthalmol. 2018, 38, 198-199. [CrossRef]

73. Xu, Q.; Du, W.; Zhou, H.; Zhang, X.; Liu, H.; Song, H.; Wang, X.; Wei, S. Distinct clinical characteristics of paraneoplastic optic neuropathy. Br. J. Ophthalmol. 2019, 103, 797-801. [CrossRef]

74. Nakajima, M.; Uchibori, A.; Ogawa, Y.; Miyazaki, T.; Ichikawa, Y.; Kaneko, K.; Takahashi, T.; Nakashima, I.; Shiraishi, H.; Motomura, M.; et al. CV2/CRMP5-antibody-related Paraneoplastic Optic Neuropathy Associated with Small-cell Lung Cancer. Intern. Med. 2018, 57, 1645-1649. [CrossRef]

75. Hernández-Bel, L.; Puchades-Gimeno, F.; Fernandez-Diaz, A.; Mata-Moret, L.; Beltrán-Catalán, E.; Hernandez-Garfella, M.L.; Cervera-Taulet, E. CRMP-5-IgG Antibody: Role in the bilateral uveitis with swollen disc. Rom. J. Ophthalmol. 2020, 64, 217-221. [CrossRef]

76. Adamus, G.; Webb, S.; Shiraga, S.; Duvoisin, R.M. Anti-recoverin antibodies induce an increase in intracellular calcium, leading to apoptosis in retinal cells. J. Autoimmun. 2006, 26, 146-153. [CrossRef] 
77. Adamus, G.; Brown, L.; Weleber, R.G. Molecular biomarkers for autoimmune retinopathies: Significance of anti-transducin-alpha autoantibodies. Exp. Mol. Pathol. 2009, 87, 195-203. [CrossRef] [PubMed]

78. Adamus, G. Autoantibody Targets and their Cancer Relationship in the Pathogenicity of Paraneoplastic Retinopathy. Autoimmun. Rev. 2009, 8, 410-414. [CrossRef] [PubMed]

79. Grange, L.; Dalal, M.; Nussenblatt, R.B.; Sen, H.N. Autoimmune retinopathy. Am. J. Ophthalmol. 2014, 157, 266-272. [CrossRef] [PubMed]

80. ten Berge, J.C.; van Rosmalen, J.; Vermeer, J.; Hellström, C.; Lindskog, C.; Nilsson, P.; Qundos, U.; Rothova, A.; Schreurs, M.W.J. Serum Autoantibody Profiling of Patients with Paraneoplastic and Non-Paraneoplastic Autoimmune Retinopathy. PLoS ONE 2016, 11. [CrossRef]

81. Ohguro, H.; Yokoi, Y.; Ohguro, I.; Mamiya, K.; Ishikawa, F.; Yamazaki, H.; Metoki, T.; Takano, Y.; Ito, T.; Nakazawa, M. Clinical and immunologic aspects of cancer-associated retinopathy. Am. J. Ophthalmol. 2004, 137, 1117-1119. [CrossRef] [PubMed]

82. Narayan, D.S.; Wood, J.P.M.; Chidlow, G.; Casson, R.J. A review of the mechanisms of cone degeneration in retinitis pigmentosa. Acta Ophthalmol. 2016, 94, 748-754. [CrossRef] [PubMed]

83. Machida, S.; Ohguro, H.; Ishida, K.; Suzuki, M.; Kawagishi, K. Recoverin-associated retinopathy secondary to Warthin tumor of parotid gland. Doc. Ophthalmol. 2014, 129, 123-128. [CrossRef] [PubMed]

84. Berson, D.M.; Dunn, F.A.; Takao, M. Phototransduction by retinal ganglion cells that set the circadian clock. Science 2002, 295, 1070-1073. [CrossRef]

85. Adamus, G.; Yang, S.; Weleber, R.G. Unique epitopes for carbonic anhydrase II autoantibodies related to autoimmune retinopathy and cancer-associated retinopathy. Exp. Eye Res. 2016, 147, 161-168. [CrossRef]

86. Zhou, R.; Horai, R.; Mattapallil, M.J.; Caspi, R.R. A new look at immune privilege of the eye: Dual role for the vision-related molecule, retinoic acid. J. Immunol. 2011, 187, 4170-4177. [CrossRef]

87. Zhou, R.; Horai, R.; Silver, P.B.; Mattapallil, M.J.; Zárate-Bladés, C.R.; Chong, W.P.; Chen, J.; Rigden, R.C.; Villasmil, R.; Caspi, R.R. The living eye "disarms" uncommitted autoreactive T cells by converting them to Foxp3(+) regulatory cells following local antigen recognition. J. Immunol. 2012, 188, 1742-1750. [CrossRef]

88. Maeda, A.; Maeda, T.; Liang, Y.; Yenerel, M. Effects of cytotoxic T lymphocyte antigen 4 (CTLA4) signaling and locally applied steroid on retinal dysfunction by recoverin, cancer-associated retinopathy antigen. Mol. Vis. 2006, 885-891.

89. Narbute, K.; Pilipenko, V.; Pupure, J.; Klinovičs, T.; Auders, J.; Jonavičè, U.; Kriaučiūnaitè, K.; Pivoriūnas, A.; Kluša, V. Time-Dependent Memory and Gait Improvement by Intranasally-Administered Extracellular Vesicles in Parkinson's Disease Model Rats. Cell. Mol. Neurobiol. 2020. [CrossRef]

90. Tarasov, V.V.; Svistunov, A.A.; Chubarev, V.N.; Dostdar, S.A.; Sokolov, A.V.; Brzecka, A.; Sukocheva, O.; Neganova, M.E.; Klochkov, S.G.; Somasundaram, S.G.; et al. Extracellular vesicles in cancer nanomedicine. Semin. Cancer Biol. 2019. [CrossRef]

91. Roberson, C.D.; Atay, S.; Gercel-Taylor, C.; Taylor, D.D. Tumor-derived exosomes as mediators of disease and potential diagnostic biomarkers. Cancer Biomark. 2010, 8, 281-291. [CrossRef] [PubMed]

92. Javeed, N.; Sagar, G.; Dutta, S.K.; Smyrk, T.C.; Lau, J.S.; Bhattacharya, S.; Truty, M.; Petersen, G.M.; Kaufman, R.J.; Chari, S.T;; et al. Pancreatic Cancer-Derived Exosomes Cause Paraneoplastic $\beta$-cell Dysfunction. Clin. Cancer Res. 2015, 21, 1722-1733. [CrossRef] [PubMed]

93. Tawil, N.; Spinelli, C.; Bassawon, R.; Rak, J. Genetic and epigenetic regulation of cancer coagulome - lessons from heterogeneity of cancer cell populations. Thrombosis Res. 2020, 191, S99-S105. [CrossRef]

Publisher's Note: MDPI stays neutral with regard to jurisdictional claims in published maps and institutional affiliations.

(C) 2020 by the authors. Licensee MDPI, Basel, Switzerland. This article is an open access article distributed under the terms and conditions of the Creative Commons Attribution (CC BY) license (http://creativecommons.org/licenses/by/4.0/). 